\title{
Growth and Physiological Responses of Maize and Sorghum Genotypes to Salt Stress
}

\author{
Genhua Niu, ${ }^{1}$ Wenwei Xu, ${ }^{2}$ Denise Rodriguez, ${ }^{1}$ and Youping Sun ${ }^{1}$ \\ ${ }^{1}$ Texas AgriLife Research, The Texas A\&M University System, 1380 A\&M Circle, El Paso, TX 79927, USA \\ ${ }^{2}$ Texas AgriLife Research, The Texas A\&M University System, 1102 East FM 1294, Lubbock, TX 79403, USA
}

Correspondence should be addressed to Genhua Niu, gniu@ag.tamu.edu

Received 27 August 2012; Accepted 11 September 2012

Academic Editors: W. P. Williams and L. Zeng

Copyright ( $) 2012$ Genhua Niu et al. This is an open access article distributed under the Creative Commons Attribution License, which permits unrestricted use, distribution, and reproduction in any medium, provided the original work is properly cited.

\begin{abstract}
The growth and physiological responses of four maize inbred lines (CUBA1, B73, B5C2, and BR1) and four sorghum hybrids (SS304, NK7829, Sordan 79, and KS585) to salinity were determined. Fifteen days after sowing, seedlings were irrigated with nutrient solution (control) at electrical conductivity (EC) of $1.5 \mathrm{dS} \mathrm{m}^{-1}$ or saline solution at EC of $8.0 \mathrm{dS} \mathrm{m} \mathrm{m}^{-1}$ (salt treatment) for 40 days. Dry weight of shoots in maize was reduced by 58\%, 65\%, 62\%, and 69\% in CUBA1, B73, B5C2, and BR1, respectively, while that of sorghum was reduced by 51\%,56\%,56\%, and 76\% in SS304, NK7829, Sordan79, and KS585, respectively, in the salt treatment compared to their respective control. Salinity stress reduced all or some of the gas exchange parameters, leaf transpiration $(E)$, stomatal conductance $\left(g_{s}\right)$, and net photosynthetic rate $\left(P_{n}\right)$ in the late part of the experiment for both crops. Salinity treatment greatly increased $\mathrm{Na}^{+}$uptake in all maize genotypes but did not affect the $\mathrm{Na}^{+}$uptake in sorghum, regardless of genotype. In maize, CUBA1 was slightly more resistant to salt stress, while BR1 was more sensitive to salt stress. In sorghum, Sordan79 was the most tolerant genotype, and KS585 was the least tolerant genotype.
\end{abstract}

\section{Introduction}

Soil salinity is one of the major environmental stresses that adversely affect plant growth and development. More than 800 million hectares of land throughout the world are salt affected, either by salinity (397 million ha) or the associated condition of sodicity (434 million ha) [1]. Effects of salinity on crop productivity are more severe in arid and semiarid regions where limited rainfall, high evapotranspiration, high temperature, poor water quality, and poor soil management practices exacerbate salinity effect [2]. As world population increases rapidly, the demand for maize and sorghum to meet the food and nonfood requirement necessitates crop production in marginal lands. Marginal land refers to land with low inherent productivity, that has been abandoned or degraded, or is of low quality for agricultural uses [3]. Most marginal lands are located in arid and semiarid regions where soil salinity is often too high for optimal production for most common economic crops and groundwater with high salinity is the primary water source. Therefore, identifying salt-tolerant crops and improving salt tolerance for salt-affected lands are critically important.

Salinity affects plants through osmotic stress and ion imbalance and toxicity [4]. Osmotic effects are due to saltinduced decrease in the soil water potential. High salts inside the plant take time to accumulate before they affect plant function. Plants have developed a wide range of mechanisms to sustain productivity under salt stress environment. These mechanisms are osmotic adjustment, $\mathrm{Na}^{+}$and/or $\mathrm{Cl}^{-}$ exclusion, and tissue tolerance of high concentrations of $\mathrm{Na}^{+}$ and/or $\mathrm{Cl}^{-}$[4]. Research on salt tolerance of various crops has indicated that salt tolerance depends largely on genera and species and even on cultivars within certain species.

Maize (Zea mays L.) was considered moderately salt sensitive [5-7], while sorghum (Sorghum bicolor (L.) Moench)) was characterized as moderately tolerant to salinity $[8,9]$. Selection and breeding have always been conducted to achieve high yield and better quality of crops under stressful conditions. Maize is a highly cross-pollinated crop and has become highly polymorphic through the course of natural and domesticated evolution and thus contains enormous 
variability in which salinity tolerance may exist [5]. Maize is not only a food product; more importantly, maize-derived products have been used in various aspects in our daily life. Sorghum is a major grain and forage, crop and both maize and sorghum are considered potential bioenergy crops in recent years. Large variations in salt tolerance among genotypes have been reported for sorghum [10-12]. With this economic importance and variability in salt tolerance among genotypes, a high-throughput method to screen salt tolerance and the development of maize and sorghum varieties for salt tolerance for salt-affected areas is urgently needed.

The purpose of this study was to assess the salt tolerance of four maize inbred lines and four sorghum hybrids. Growth, gas exchange rates, leaf chlorophyll fluorescence, relative chlorophyll content, and tissue ion accumulation of the selected maize and sorghum genotypes were investigated when irrigated with saline or nonsaline solutions. Physiological response of crops to salinity is valuable information for breeding programs.

\section{Materials and Methods}

2.1. Experimental Design and Treatments. Seeds of four maize inbred lines (CUBA1, B73, B5C2, and BR1) and four sorghum hybrids (SS304, NK7829, Sordan79, and KS585) were sown in $2.6 \mathrm{~L}$ containers, 4 seeds per container, filled with commercial potting mix (Sunshine Mix number 4, SunGro Hort., Bellevue, WA). B73 was a temperate line developed by the Iowa State University, while the other three lines were developed by Wenwei $\mathrm{Xu}$ using the temperate and tropical crosses. Four sorghum hybrids were provided by Sorghum Partners, Inc. [13]. KS585 and NK7829 are grain type hybrids. SS304 and Sordan 79 are forage sorghum hybrids. Sordan 79 is a sorghum x sudangrass hybrid and good for alkali soils due to its salt tolerance. Seedlings were thinned to one per container 10 days after sowing. Two weeks after sowing, treatments were initiated by irrigating seedlings with nutrient solution or saline solution, $1 \mathrm{~L}$ per container. The nutrient solution with electrical conductivity (EC) of $1.5 \mathrm{dS} \mathrm{m}^{-1}$ was prepared by adding $0.5 \mathrm{~g} \mathrm{~L}^{-1}$ of $20 \mathrm{~N}-8.6 \mathrm{P}-$ 16.7 K (Peters 20-20-20; Scotts) to tap water. The major ions in the tap water were $\mathrm{Na}^{+}, \mathrm{Ca}^{2+}, \mathrm{Mg}^{2+}, \mathrm{Cl}^{-}$, and $\mathrm{SO}_{4}{ }^{2-}$ at $184,52.0,7.5,223.6$, and $105.6 \mathrm{mg} \mathrm{L}^{-1}$, respectively. Saline solutions at EC of $3.0 \mathrm{dS} \mathrm{m}^{-1}$ (first irrigation) or $8.0 \mathrm{dS} \mathrm{m}^{-1}$ (second irrigation and after) were prepared by adding calculated amounts of sodium chloride $(\mathrm{NaCl})$, magnesium sulfate $\left(\mathrm{MgSO}_{4} \cdot 7 \mathrm{H}_{2} \mathrm{O}\right)$, and calcium chloride $\left(\mathrm{CaCl}_{2}\right)$ at $87: 8: 5$ (weight ratio) to the nutrient solution. The experiment followed a split-plot design with salinity as the main plot and genotype as subplot. Greenhouse environmental conditions were maintained at air temperature at $33.6 \pm 1.1^{\circ} \mathrm{C}$ during the day and $20.4 \pm 1.5^{\circ} \mathrm{C}$ at night, relative air humidity at $20.4 \pm 3.3 \%$, and daily light integral (photosynthetically active radiation) at $21.4 \pm 2.3 \mathrm{~mol} \mathrm{~m}^{-2} \mathrm{~d}^{-1}$.

2.2. Measurement. Upon termination of the experiment ( 40 days after the initiation of treatment), shoots were severed at the substrate surface and were separated into leaves and stems for maize or separated into stalks and tillers for sorghum. The number of tillers was recorded for sorghum. Dry weights of separated tissue were determined after oven dried at $70^{\circ} \mathrm{C}$ to constant weight. In order to monitor salt accumulation in the root zone, leachate was collected periodically and the EC of the leachate was measured using an EC meter (Model B-173, Horiba, Ltd., Japan). Solution was diluted properly whenever the leachate EC exceeded $20 \mathrm{dS} \mathrm{m}^{-1}$ by adding deionized water to obtain the actual EC accurately because the maximum range of the EC meter is $20 \mathrm{dS} \mathrm{m} \mathrm{m}^{-1}$. To reduce the salt accumulation, plants were flushed with tap water to lower the salinity in the root zone.

2.2.1. Gas Exchange Rates. Leaf net photosynthesis $\left(P_{n}\right)$, transpiration $(E)$, and stomatal conductance $\left(g_{s}\right)$ were measured on four plants per genotype per treatment on 15,30 , and 35 days after the initiation of treatment by placing the recently matured leaf in the cuvette of a portable gas exchange measurement system (CIRAS-2, PP Systems, Amesbury, MA). The environmental conditions in the cuvette were controlled at leaf temperature $=25^{\circ} \mathrm{C}$, photosynthetic photon flux $(\mathrm{PPF})=1000 \mu \mathrm{mol} \mathrm{m}{ }^{-2} \mathrm{~s}^{-1}$, and $\mathrm{CO}_{2}$ concentration $=400 \mu \mathrm{mol} \mathrm{mol}^{-1}$. Data were recorded when the environmental conditions and gas exchange parameters in the cuvette became stable. These measurements were taken on sunny days between $1000 \mathrm{HR}$ and $1400 \mathrm{HR}$ and plants were well watered to avoid water stress.

2.2.2. Chlorophyll Fluorescence. In order to examine the influence of progressively increased salt stress on leaf photosynthetic apparatus among the genotypes, leaf chlorophyll fluorescence values, minimal fluorescence $F_{o}$, maximum fluorescence $F_{m}$, variable fluorescence $F_{v}$, and the maximal photochemical efficiency of photosynthesis system II, $F_{v} / F_{m}\left(F_{v}=F_{m}-F_{o}\right)$, were measured on three days during the experiment on young, fully expanded leaves using a Plant Efficiency Analyzer (Hansatech Instruments Ltd., Kings Lynn, UK). Before the measurement, leaves were darkadapted for $10 \mathrm{~min}$ by using the light-exclusion clips.

2.2.3. Relative Chlorophyll Content. Leaf greenness (or relative chlorophyll content) was measured using a hand-held chlorophyll meter (measured as the optical density, SPAD reading, Minolta Camera Co., Osaka, Japan) at the end of the experiment for all plants (10 plants per treatment) in each treatment [14]. SPAD readings of three leaves per plant selected from the middle sections of the plant were measured. All plants were well watered when this measurement was taken.

2.2.4. Mineral Analysis. Four samples per tissue per treatment were collected for mineral analysis of $\mathrm{Na}^{+}, \mathrm{Ca}^{2+}$, $\mathrm{Mg}^{2+}$, and $\mathrm{Cl}^{-}$at the end of the experiment. For maize genotypes, leaves and stems were separately sampled while for sorghum, stalks and tillers were separately sampled. Dried tissue was ground with a stainless Wiley mill (Thomas Scientific, Swedesboro, NJ), and ground samples were sent 


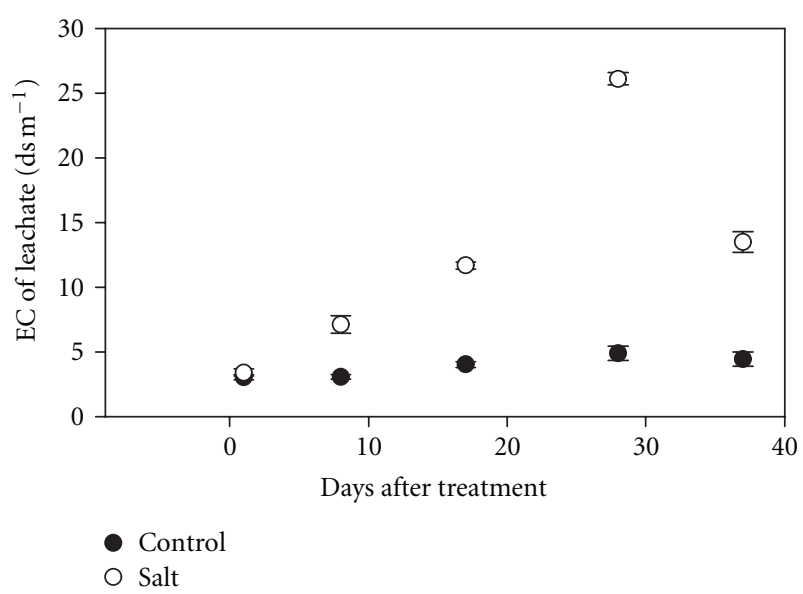

FIGURE 1: Leachate EC pooled from four maize genotypes (CUBA1, B73, B5C2, and BR1) and four sorghum genotypes (SS304, NK7829, Sordan79, and KS585) measured during the treatment period when irrigated with nutrient solution at EC of $1.5 \mathrm{dS} \mathrm{m}^{-1}$ or saline solution at EC of $8.0 \mathrm{dS} \mathrm{m}^{-1}$ for 40 days (replication of 4).

to an analytical lab for mineral analysis (SWAT laboratory at New Mexico State University, Las Cruces, NM). The $\mathrm{Na}^{+}, \mathrm{Ca}^{2+}$, and $\mathrm{Mg}^{2+}$ concentrations were determined by EPA method 200.7 [15] and analyzed on an ICAP Trace Analyzer (Thermo Jarrell Ash, Franklin, MA). Chloride was determined by EPA method 300.0 [15] and analyzed using an Ion Chromatograph (Dionex, Sunnyville, CA).

2.3. Statistical Analysis. All analyses were carried out separately for maize and sorghum due to obvious differences in growth. Analysis of variance was carried out to determine the effects of salt and genotype for each crop. When genotype effect was significant, means were separated by StudentNewman-Keuls (SNK) multiple comparisons at $P=0.05$. When salt effect was significant, $t$-test was carried out to determine the significance. All statistical analyses were performed using SAS (version 9.1.3; SAS Institute, Cary, $\mathrm{NC}$.

\section{Results and Discussion}

3.1. Growth, Foliar Salt Damage, and Substrate Salinity. Leachate salinity in the salt treatment increased with time due to salt accumulation in the peat-based substrate, while that of control did not change substantially (Figure 1). Four weeks after the initiation of treatment, leachate salinity in the salt treatment increased to $26 \mathrm{dS} \mathrm{m}^{-1}$. The substrate was flushed with tap water to leach out salts and prevent excessive salt accumulation. At the end of the experiment, the EC was decreased to $13.5 \mathrm{dS} \mathrm{m}^{-1}$. Salt accumulation depends on the substrate property, salinity of the irrigation water, leaching fraction, and frequency of the irrigation. As indicated in this study, irrigating with saline water led to salt accumulation in the root zone. In reality, the salinity of irrigation water would not be as high as $8.0 \mathrm{dS} \mathrm{m}^{-1}$ as used in this study. The reason for choosing this EC was to distinguish the salt tolerance among the genotypes in a relatively short term, in this case, 40 days.

Among the four genotypes of maize, BR1, an inbred line with $50 \%$ tropical germplasm, had the most obvious leaf salt damage with leaf rolling and yellowing in some young leaves (data not shown). B73 and $\mathrm{B} 5 \mathrm{C} 2$ had leaf rolling. CUBA1 did not exhibit any visible salt damage. Therefore, in terms of foliar salt damage, BR1 was the least tolerant, while CUBA1 was the least sensitive to salt stress. CUBA1 is an inbred line developed with a cross between a temperate line and the tropical Cuba flint, and was selected for heat and drought tolerance. Among the four genotypes of sorghum, KS585 had the most severe leaf edge burn and leaf yellowing, followed by NK7929; SS304 had minor leaf edge burn, while Sordan79 looked healthy without any salt damage. It was obvious that Sordan 79 was the most tolerant and KS585 was the least tolerant among the sorghum and maize genotypes. The high salt tolerance of Sordan 79 in the greenhouse agreed with extensive field testing under various soil conditions. Sordan 79 is a sorghum-and-sudangrass hybrid for forage production and well adapted to alkali soils [13].

For maize, dry weights of leaves and stems were reduced by elevated salinity in all genotypes compared to those of the control (Figure 2). Total dry weight of shoots was reduced by $58 \%, 65 \%, 62 \%$, and $69 \%$ in CUBA $1, \mathrm{~B} 73, \mathrm{~B} 5 \mathrm{C} 2$, and $\mathrm{BR} 1$, respectively, in the salt treatment compared to their respective control. Therefore, in term of growth, BR1 was less tolerant to salt stress among the four genotypes, while CUBA1 was relatively more tolerant to salt stress. The relative salt tolerance based on growth was in agreement with that in terms of foliar salt damage.

For sorghum, salinity treatment did not affect the number of tillers (not presented) but affected the dry weight of tillers except for NK7829 where no tiller was observed in the control (Figure 3). The reduction of dry weight of stalk (shoots excluding tillers) due to elevated salinity was highest in KS585 (79\%) and lowest in Sordan79 and SS304 (38\% and $39 \%)$. Total dry weight of shoots was reduced by $51 \%, 56 \%, 56 \%$, and $76 \%$ in SS304, NK7829, Sordan79, and KS585, respectively, in the salt treatment compared to their respective control. Therefore, combined with the visual salt damage ratings, Sordan79 was the most tolerant, followed by SS304, while KS585 was the least tolerant among the eight genotypes (both maize and sorghum). Although total shoot dry weight reduction was smaller in SS304 compared to that of Sordan79, Sordan79 was still considered to be the most tolerant because SS304 did exhibit some leaf edge burn.

3.2. Gas Exchange Rates. For maize, gas exchange rates $E$, $g_{s}$, and $P_{n}$ of all genotypes on Day 15 were not affected by salt stress (Figure 4). However, on Day 30 and Day 35, all gas exchange rates were reduced significantly by salt stress. The reduction percentages caused by elevated salt stress were approximately $60 \%$ in $E, 80 \%$ in $g_{s}$, and $45 \%$ in $P_{n}$, indicating that effect of salt stress on $P_{n}$ was the least, while that on $g_{s}$ was the greatest. No differences in $E, g_{s}$, and $P_{n}$ among genotypes were found on all measurement days for the same treatment. For the control plants, $E$ was higher 

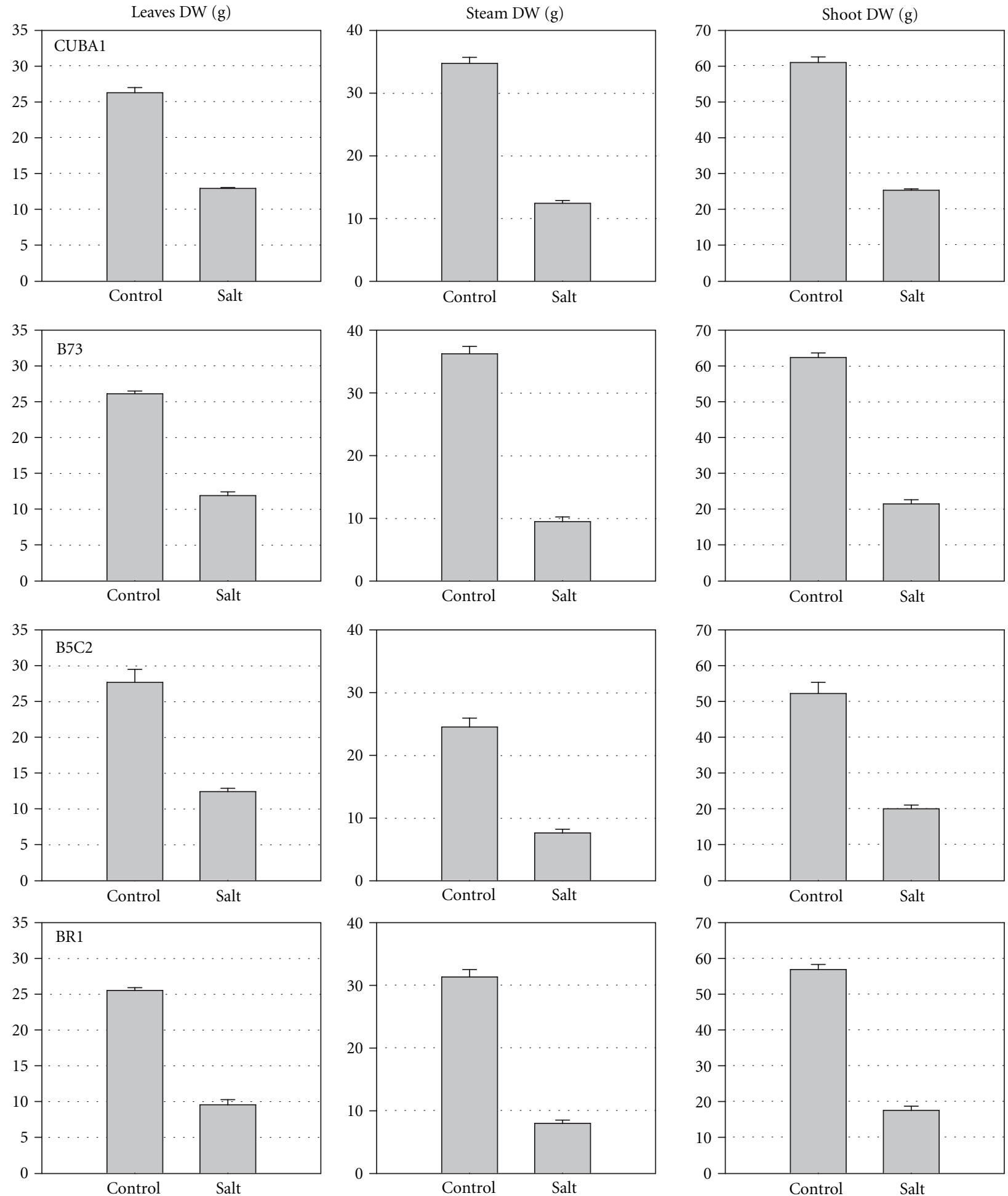

Figure 2: Dry weight of leaves, stems, and shoot of four maize genotypes (CUBA1, B73, B5C2, and BR1) when irrigated with nutrient solution at EC of $1.5 \mathrm{dS} \mathrm{m}^{-1}$ or saline solution at EC of $8.0 \mathrm{dS} \mathrm{m}^{-1}$ for 40 days. Vertical bars represent standard errors (replication of 10).

on Day 30 and Day 35 for CUBA1 and B5C2, although not statistically significant, those of B73 and BR1 were also numerically higher on Day 30 and Day 35 compared to Day 15 . For BR1, $E$ and $P_{n}$ did not change significantly over time, although numerically they did decrease compared to those on Day 15. Generally, salt stress reduced gas exchange rates, while no substantial differences were found among genotypes. 

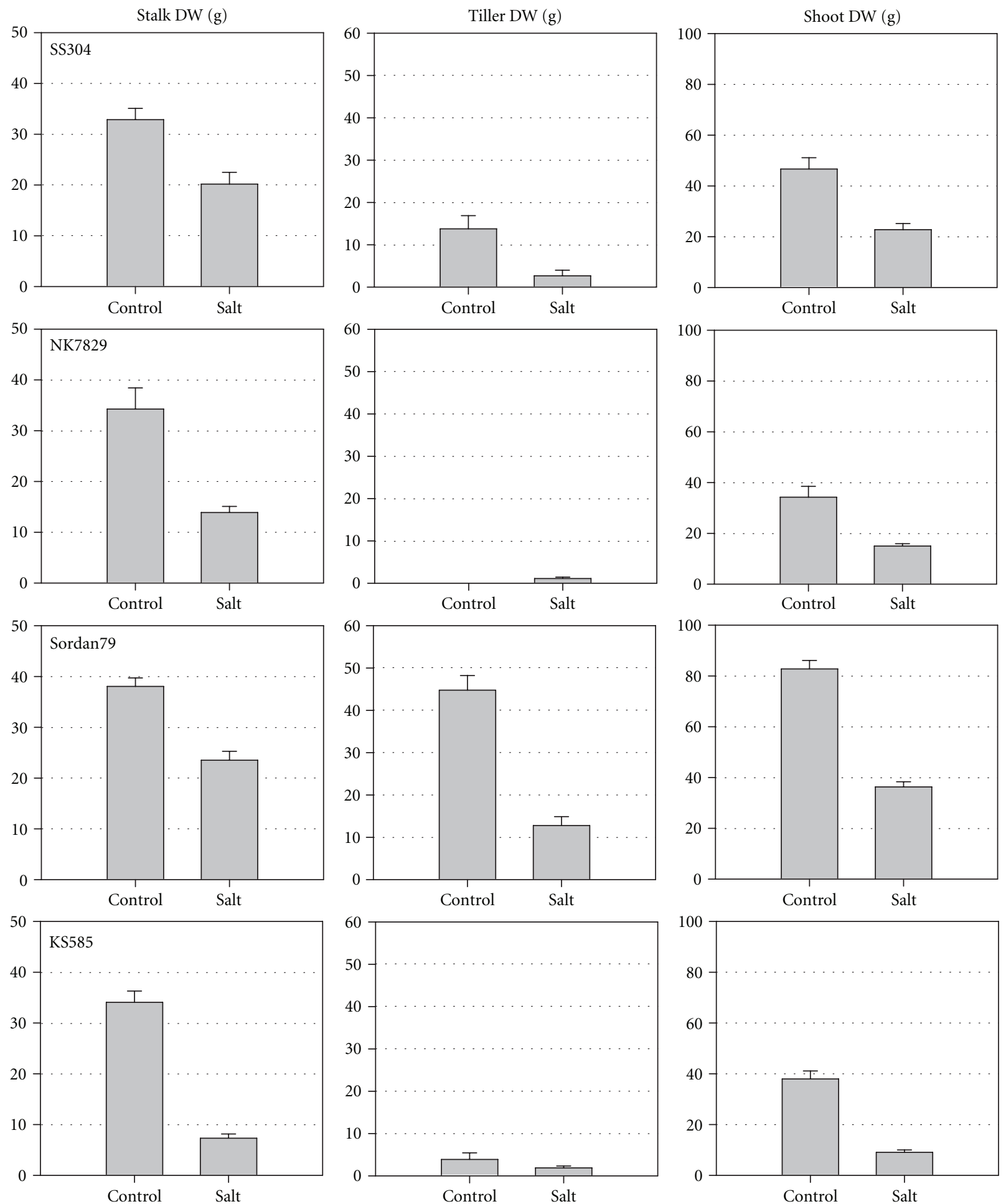

FIGURE 3: Dry weight of stalks, tillers, and shoots of four sorghum genotypes (SS304, NK7829, Sordan79, and KS585) when irrigated with nutrient solution at EC of $1.5 \mathrm{dS} \mathrm{m}^{-1}$ or saline solution at EC of $8.0 \mathrm{dS} \mathrm{m}^{-1}$ for 40 days. Vertical bars represent standard errors (replication of 10).

For sorghum, on Day 15, salt treatment did not affect $E$, $g_{s}$, and $P_{n}$ of the plants, except for $P_{n}$ of NK 7829 (Figure 5). On Day 30, salt treatment did not affect $E$, $g_{s}$, and $P_{n}$, except for $g_{s}$ and $P_{n}$ of KS585. The $g_{s}$ and $P_{n}$ of KS585 were reduced by $50 \%$ and $16 \%$ in salt treatment compared to control. On Day 35 , salt treatment significantly reduced $E, g_{s}$, and $P_{n}$ of NK7829 and KS585, $E$ and $P_{n}$ of Sordan79, and $P_{n}$ of SS304. 

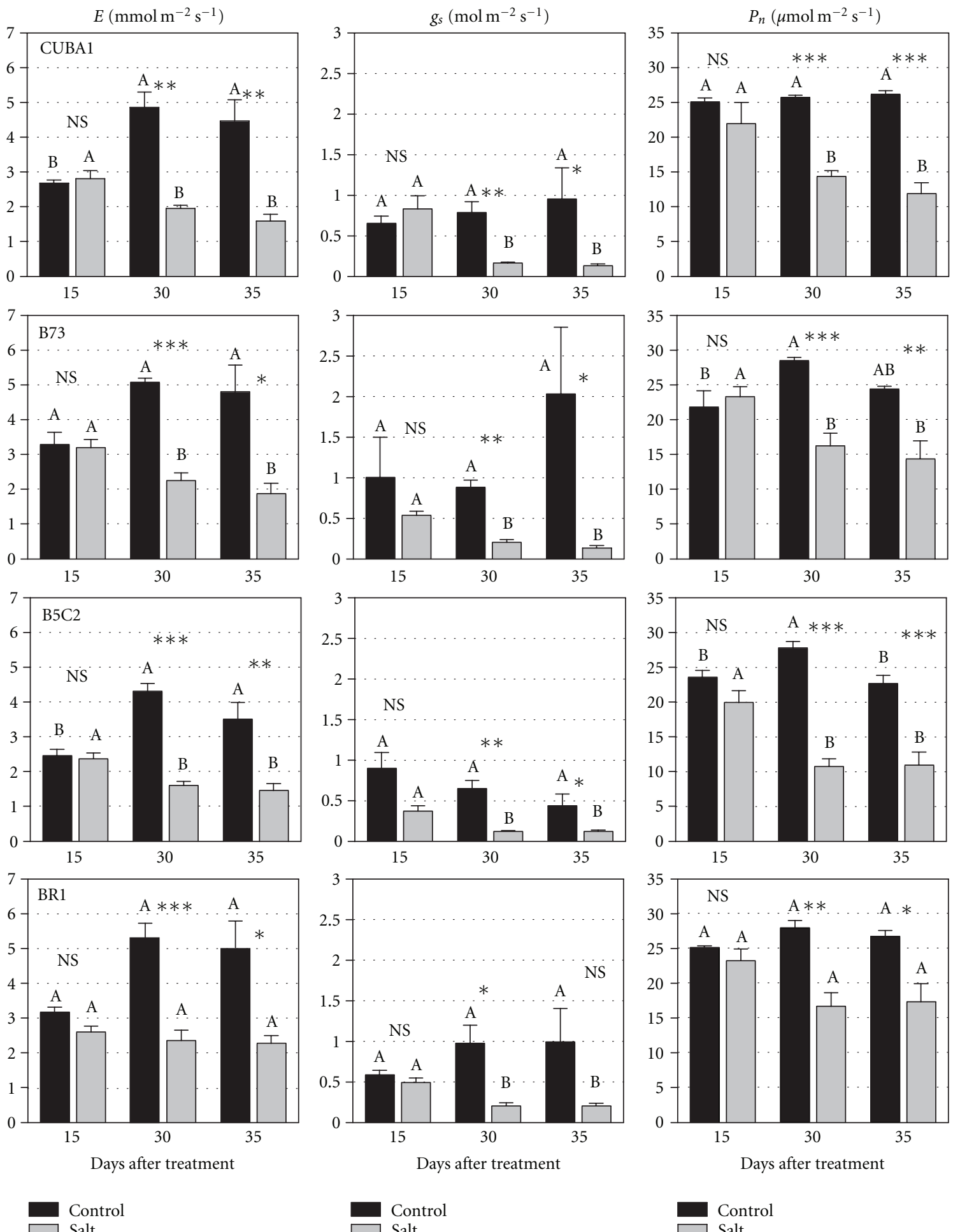

Figure 4: Leaf gas exchange rates, transpiration $(E)$, stomatal conductance $\left(g_{s}\right)$, and net photosynthetic rate $\left(P_{n}\right)$ of four maize genotypes (CUBA1, B73, B5C2, and BR1) when irrigated with nutrient solution at EC of $1.5 \mathrm{dS} \mathrm{m}^{-1}$ or saline solution at EC of $8.0 \mathrm{dS} \mathrm{m}^{-1}$ for $40 \mathrm{days}$. Means with the same letters on different days are not significantly different tested by Student-Newman-Keuls (SNK) multiple comparisons at $P=0.05$. ${ }^{* *},{ }^{* *},{ }^{*}$, and NS are significant at $P=0.0001,0.01,0.05$, or nonsignificant between the two treatments by $t$-test. Vertical bars represent standard errors (replication of 4). 

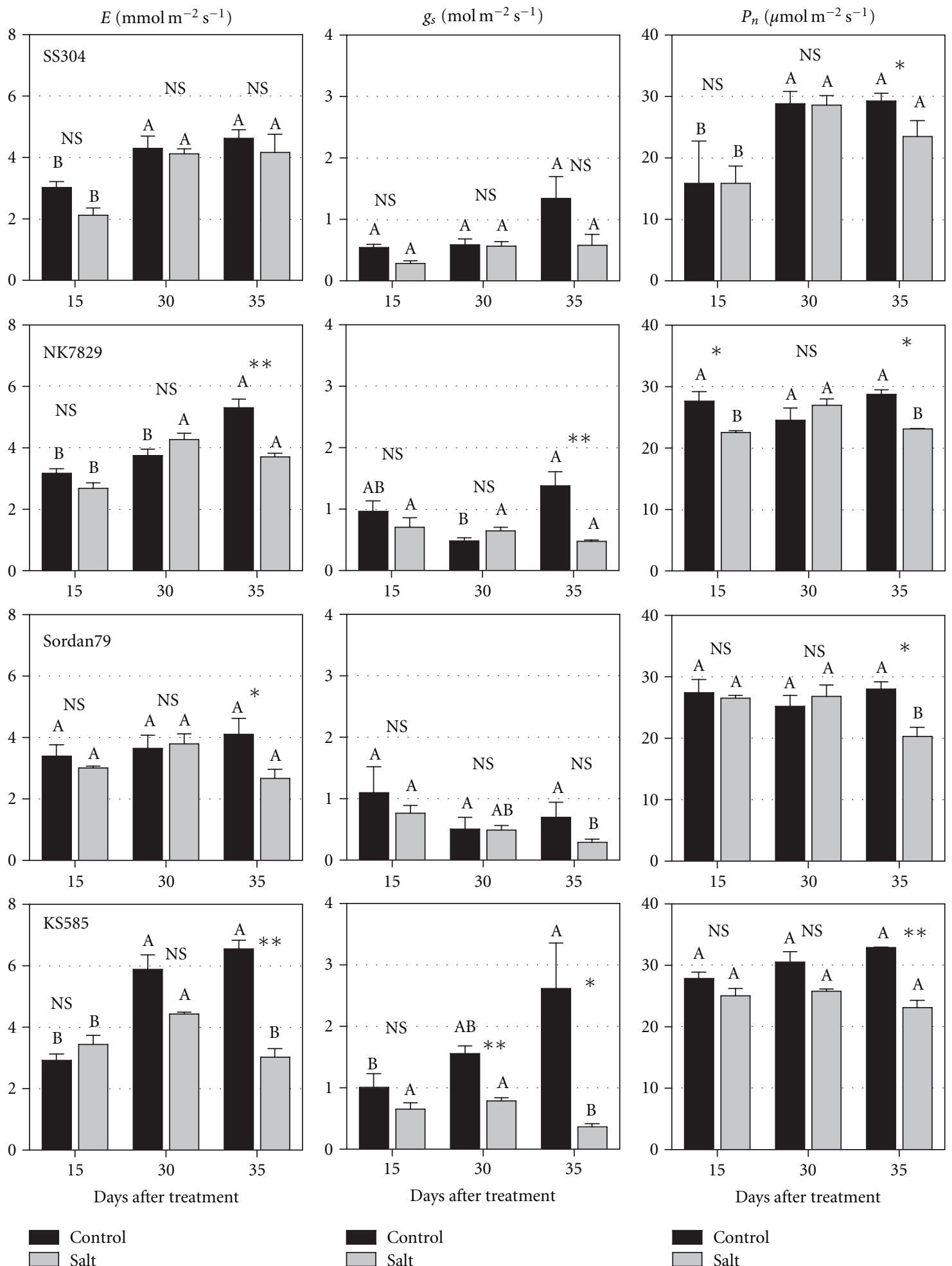

FIGURE 5: Leaf gas exchange rates, transpiration $(E)$, stomatal conductance $\left(g_{s}\right)$, and net photosynthetic rate $\left(P_{n}\right)$ of four sorghum genotypes (SS304, NK7829, Sordan79, and KS585) when irrigated with nutrient solution at EC of $1.5 \mathrm{dS} \mathrm{m}^{-1}$ or saline solution at EC of $8.0 \mathrm{dS} \mathrm{m}{ }^{-1}$ for 40 days. Means with the same letters on different days are not significantly different tested by Student-Newman-Keuls (SNK) multiple comparisons at $P=0.05 .{ }^{* *},{ }^{* *},{ }^{*}$, and NS are significant at $P=0.0001,0.01,0.05$, or nonsignificant between the two treatments by $t$-test. Vertical bars represent standard errors (replication of 4 ). 
As soil salinity increases, leaf gas exchange rates decrease for many crops. At low or moderate soil salinity, decreased growth is primarily associated with a reduction in photosynthetic area rather than a reduction in net photosynthetic rate per unit leaf area [16]. At high salinity, however, leaf photosynthesis can be reduced by lowered stomatal conductance or by nonstomatal factors that may be caused by toxic ions, as indicated by many researchers $[17,18]$. It must be pointed out that when a portable gas exchange instrument such as CIRAS-2 (used in the current study) or LI-6400 (LI-COR, Inc., Lincoln, NE) is used for gas exchange measurement, the potential rates of a selected single leaf, in most cases, a fully expanded healthy leaf, at the specified cuvette environmental conditions are measured. The negative effect of salinity on actual gas exchange rates of a whole plant is probably greater than that of a single healthy leaf because older leaves are more affected by salinity than newly developed leaves. Also, not all the leaves have the same potentials as the one measured. In the current study, a PPF of $1000 \mu \mathrm{moL} \mathrm{m}^{-2} \mathrm{~s}^{-1}$ was chosen because during that time period inside the greenhouse, the maximum instant PPF was between 800 to nearly $1000 \mu \mathrm{moL} \mathrm{m}{ }^{-2} \mathrm{~s}^{-1}$. Gas exchange rates of several cultivars of ornamental peppers (Niu, unpublished data) and roses [19] grown under nonsaline and moderate saline conditions were statistically the same when measured on a single young leaf with the same instrument as used in this study, while shoot growth was reduced significantly by the elevated salinity as seen in this study. These results may indicate that under low-to-moderate salinity, gas exchange rates of a healthy leaf are often not affected. Therefore, single leaf gas exchange rates measured under specified optimal conditions are less effective indicators to assess salt tolerance of the crop compared to visual salt damage and growth.

\subsection{Chlorophyll Fluorescence and Relative Chlorophyll Con-} tent. For maize genotypes, effect of salt on chlorophyll fluorescence parameters $F_{o}, F_{m}, F_{v}$, and $F_{v} / F_{m}$ was not consistent over time (Table 1). For example, 21 days after the treatment, salinity significantly reduced $F_{m}, F_{v}$, and $F_{v} / F_{m}$ of $\mathrm{B} 5 \mathrm{C} 2$, while for all other genotypes, no effect was observed. On Day 31, all genotypes were affected by the salt stress on one or more of the parameters. On Day 37, only $F_{o}$ of CUBA1, B73, and B5C2 was affected (increased) by salt stress, while all other parameters were not. The longer the treatment is, the more stressed the plants should be. However, chlorophyll fluorescence parameters did not indicate any sign of progressive salinity stress. This may be because every time the fully expanded new leaf was measured, instead of the same leaf on different days.

For sorghum genotypes, similar to that found in maize genotypes, the effect of salt on chlorophyll fluorescence parameters $F_{o}, F_{m}, F_{v}$, and $F_{v} / F_{m}$ was not consistent over time and even had few significances among these parameters (data not shown). These results may indicate that the salt stress on both crops may not be severe enough to cause consistent and significant damage on PSII.

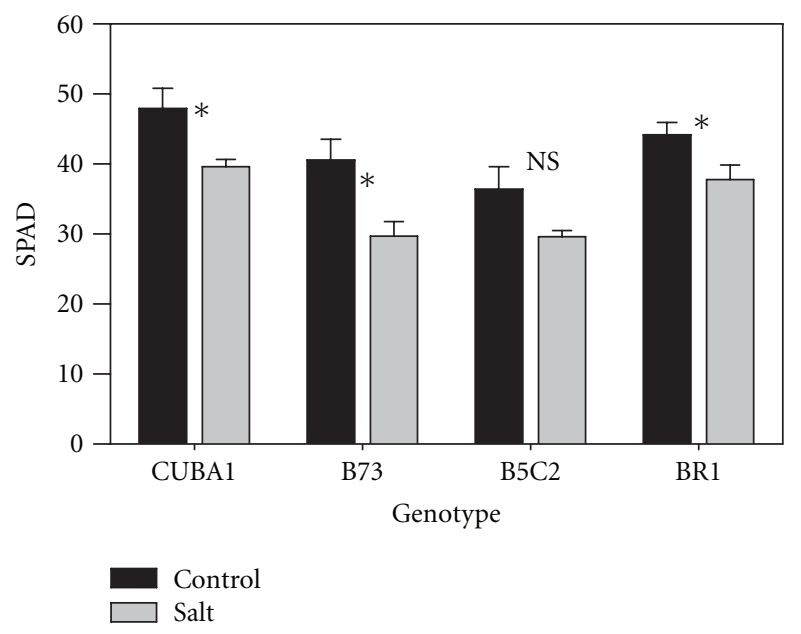

FIGURE 6: Relative chlorophyll content measured as SPAD index of four maize genotypes (CUBA1, B73, B5C2, and BR1) when irrigated with nutrient solution at $\mathrm{EC}$ of $1.5 \mathrm{dS} \mathrm{m}^{-1}$ or saline solution at $\mathrm{EC}$ of $8.0 \mathrm{dS} \mathrm{m}^{-1}$ for 40 days. ${ }^{*}$ and NS are significant at $P=0.05$ or nonsignificant between the two treatments by $t$-test. Vertical bars represent standard errors (replication of 10).

Under the combined salinity-alkalinity stress, $F_{v} / F_{m}$ of maize seedlings decreased only at high salinityalkalinity, which is $\mathrm{NaCl}$ of $100 \mathrm{mmoL} \mathrm{L}^{-1}$ and $\mathrm{NaHCO}_{3}$ of $100 \mathrm{mmoL} \mathrm{L}^{-1}$ [20]. Another study also reported that a decline in $F_{v} / F_{m}$ of maize was minimal when plants were exposed to salinity levels lower than $10 \mathrm{dS} \mathrm{m}^{-1}$, while a significant difference in $F_{v} / F_{m}$ occurred at the higher salinity levels [21]. Similar effect of salinity on $F_{v} / F_{m}$ in sorghum was reported [22]. These studies may indicate that $F_{v} / F_{m}$ was an appropriate tool to screen tolerance to salt stress for maize and sorghum at low salinity level; however, it may be useful at high salinity levels.

For maize genotypes, relative chlorophyll content measured as SPAD value at the end of the experiment was reduced by salt stress in CUBA1, B73, and BR1, while that of $\mathrm{B} 5 \mathrm{C} 2$ was numerically reduced but not significant statistically $(P=0.0677$, Figure 6). For sorghum, no differences were found in SPAD values among control and salt treatment, regardless of genotype (data not shown). Reduction of leaf chlorophyll content at high salinity stress was reported in maize [20,23-25] and other crops such as wheat [26], radish [27], and basil [28]. Again, the salinity stress was not severe enough to cause more significant differences in SPAD values for both crops between the treatments.

3.4. Ion Accumulation. For maize genotypes, significant effects of salt treatment and genotype on tissue mineral contents were observed, especially on $\mathrm{Na}^{+}$and $\mathrm{Cl}^{-}$(Table 2). $\mathrm{Na}^{+}$concentrations were generally higher in stems than in leaves for all genotypes, except for B5C2 and BR1 in the control. $\mathrm{Na}^{+}$concentrations in leaves and stems in the salt treatment were 20 to 200 times that of control. The increase in $\mathrm{Na}^{+}$concentrations in leaves and stems was even 
TABLE 1: Summary of $t$-test results on the effect of salinity on chlorophyll fluorescence parameters (initial fluorescence $F_{o}$, maximum fluorescence $F_{m}$, variable fluorescence $F_{v}$, and ratio of $F_{v} / F_{m}$ ) of four maize genotypes (CUBA1, B73, B5C2, and BR1) when irrigated with nutrient solution at EC of $1.5 \mathrm{dS} \mathrm{m}^{-1}$ or saline solution at EC of $8.0 \mathrm{dS} \mathrm{m}^{-1}$ for 40 days (replication of 6).

\begin{tabular}{|c|c|c|c|c|}
\hline Genotype & $F_{o}$ & $F_{m}$ & $F_{v}$ & $F_{v} / F_{m}$ \\
\hline \multicolumn{5}{|c|}{ Day 22} \\
\hline CUBA1 & NS & NS & NS & NS \\
\hline B73 & NS & NS & NS & NS \\
\hline B5C2 & NS & 0.0177 & 0.015 & 0.0231 \\
\hline BR1 & NS & NS & NS & NS \\
\hline \multicolumn{5}{|c|}{ Day 31} \\
\hline CUBA1 & 0.0029 & 0.0029 & 0.0085 & NS \\
\hline B73 & $<0.0001$ & NS & NS & 0.0061 \\
\hline B5C2 & 0.0013 & NS & 0.0474 & 0.0007 \\
\hline BR1 & NS & NS & NS & 0.037 \\
\hline \multicolumn{5}{|c|}{ Day 37} \\
\hline CUBA1 & 0.0232 & NS & NS & NS \\
\hline B73 & 0.0112 & NS & NS & NS \\
\hline B5C2 & 0.0468 & NS & NS & NS \\
\hline BR1 & NS & NS & NS & NS \\
\hline
\end{tabular}

NS: non-significant.

TABLE 2: Ion concentrations of leaves and stems of four maize genotypes (CUBA1, B73, B5C2, and BR1) irrigated with nutrient or saline solutions for 40 days (replication of 4 ).

\begin{tabular}{|c|c|c|c|c|c|c|}
\hline Genotype & Tissue & Treatment & \multicolumn{4}{|c|}{$\left(\mathrm{mgg}^{-1}\right)$} \\
\hline \multirow{4}{*}{ CUBA1 } & \multirow{2}{*}{ Leaves } & Control & 0.44 & 11.41 & 4.25 & 3.03 \\
\hline & & Salt & 10.05 & 19.01 & 4.28 & 2.18 \\
\hline & \multirow{2}{*}{ Stems } & Control & 1.15 & 17.57 & 3.15 & 3.65 \\
\hline & & Salt & 31.93 & 47.23 & 1.88 & 2.08 \\
\hline \multirow{4}{*}{ B73 } & \multirow{2}{*}{ Leaves } & Control & 0.43 & 12.02 & 4.73 & 4.88 \\
\hline & & Salt & 8.83 & 26.87 & 4.95 & 2.95 \\
\hline & \multirow{2}{*}{ Stems } & Control & 0.73 & 19.05 & 2.45 & 4.53 \\
\hline & & Salt & 34.98 & 54.83 & 1.88 & 1.95 \\
\hline \multirow{4}{*}{ B5C2 } & \multirow{2}{*}{ Leaves } & Control & 0.38 & 12.70 & 3.78 & 5.13 \\
\hline & & Salt & 22.18 & 37.50 & 3.95 & 3.43 \\
\hline & \multirow{2}{*}{ Stems } & Control & 0.23 & 19.52 & 4.28 & 8.13 \\
\hline & & Salt & 41.58 & 73.06 & 2.73 & 3.18 \\
\hline \multirow{4}{*}{ BR1 } & \multirow{2}{*}{ Leaves } & Control & 0.09 & 8.47 & 3.95 & 2.95 \\
\hline & & Salt & 7.35 & 18.43 & 3.95 & 2.55 \\
\hline & \multirow{2}{*}{ Stems } & Control & 0.14 & 14.99 & 3.65 & 4.68 \\
\hline & & Salt & 32.45 & 50.77 & 2.78 & 2.38 \\
\hline \multicolumn{7}{|c|}{ ANOVA Summary } \\
\hline \multicolumn{3}{|l|}{ Genotype } & 0.0013 & $<0.0001$ & NS & $<0.0001$ \\
\hline \multicolumn{3}{|l|}{ Tissue } & $<0.0001$ & $<0.0001$ & $<0.0001$ & NS \\
\hline \multicolumn{3}{|c|}{ Genotype $\times$ tissue } & NS & NS & 0.0188 & 0.0278 \\
\hline \multicolumn{3}{|l|}{ Treatment } & $<0.0001$ & $<0.0001$ & NS & $<0.0001$ \\
\hline \multicolumn{3}{|c|}{ Genotype $\times$ treatment } & 0.001 & $<0.0001$ & NS & 0.0104 \\
\hline \multicolumn{3}{|c|}{ Tissue $\times$ treatment } & $<0.0001$ & $<0.0001$ & 0.0377 & 0.0013 \\
\hline \multicolumn{3}{|c|}{ Genotype $\times$ tissue $\times$ treatment } & NS & NS & NS & NS \\
\hline
\end{tabular}

NS: non-significant. 
TABLE 3: Ion concentrations of stalks and tillers of four sorghum genotypes (SS304, NK7829, Sordan79, and KS585) irrigated with nutrient or saline solutions for 40 days (replication of 4 ).

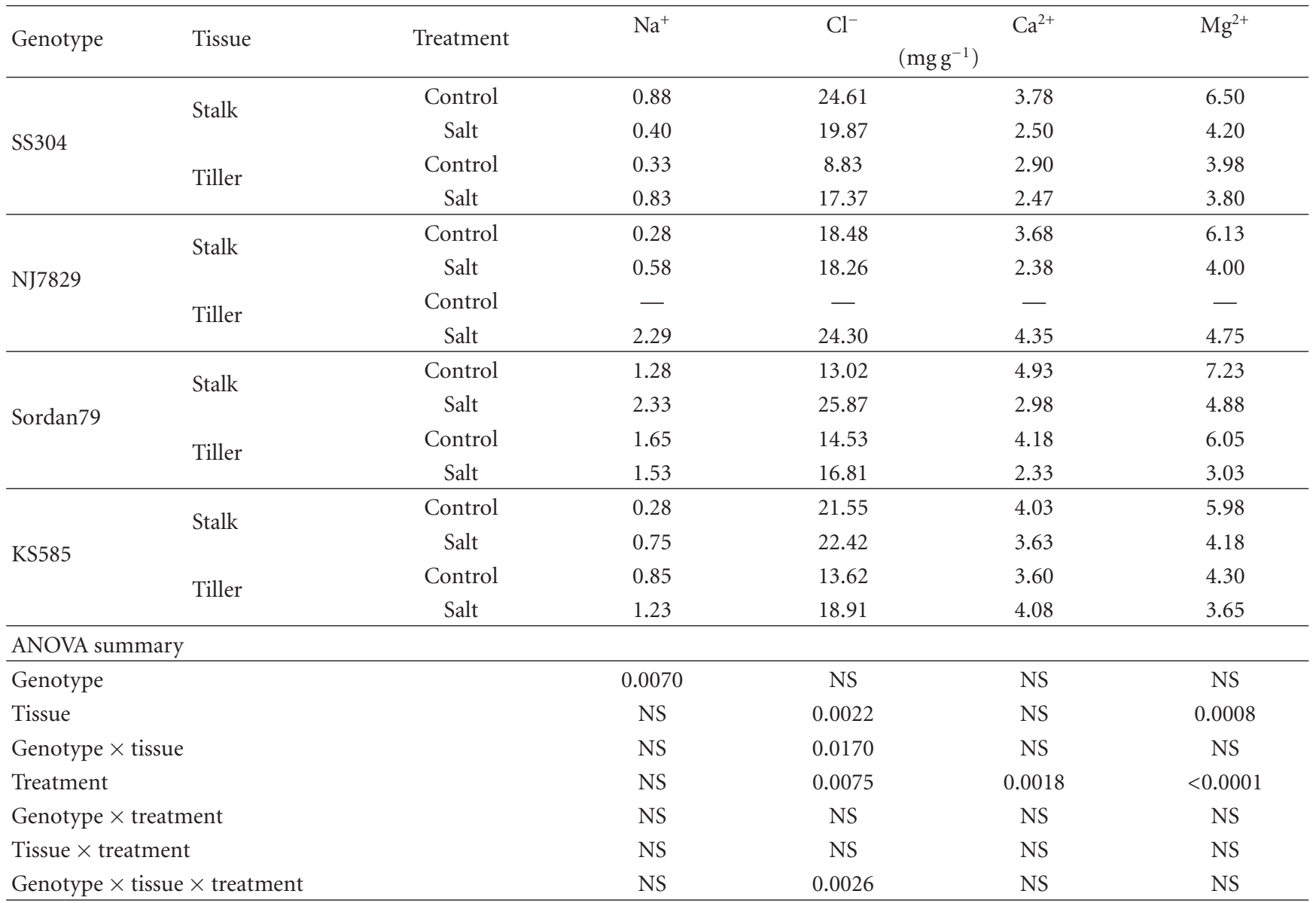

NS: non-significant.

higher in BR1 because BR1 in the control had very low concentrations of $\mathrm{Na}^{+}$in leaves and stems. Same to $\mathrm{Na}^{+}, \mathrm{Cl}^{-}$ concentrations were higher in stems than in leaves for all genotypes. $\mathrm{Cl}^{-}$concentrations in leaves and stems in the salt treatment were 1.7 to 3.7 times that of control. No significant differences in $\mathrm{Cl}^{-}$concentrations among genotypes were found. As for $\mathrm{Ca}^{2+}$, genotype and treatment did not affect $\mathrm{Ca}^{2+}$ concentration. B5C2 had higher $\mathrm{Mg}^{2+}$ concentrations compared to those of other genotypes in both control and salt treatment. Salt treatment reduced $\mathrm{Mg}^{2+}$ concentration by $30 \%$ to $50 \%$, depending on genotype and tissue.

For sorghum genotypes, $\mathrm{Na}^{+}$concentration was not affected by salinity, while all other mineral $\left(\mathrm{Cl}^{-}, \mathrm{Ca}^{2+}\right.$, and $\mathrm{Mg}^{2+}$ ) concentrations were affected by salinity (Table 3 ). Salinity increased uptake of $\mathrm{Cl}^{-}$but decreased $\mathrm{Ca}^{2+}$ and $\mathrm{Mg}^{2+}$ uptake in the stalk and tiller, although the differences in these mineral concentrations between the control and salt treatment were small. Genotype affected $\mathrm{Na}^{+}$concentrations, but not $\mathrm{Cl}^{-}, \mathrm{Ca}^{2+}$, and $\mathrm{Mg}^{2+}$ concentrations. The $\mathrm{Na}^{+}$ concentrations in Sordan79 tissue were very low compared to maize genotypes; however, they were higher compared to those of SS304 and KS585. There was no difference in $\mathrm{Na}^{+}$ between Sordan79 and NK7829, or between NK7829 and those of SS304 and KS585. Compared to maize genotypes, both $\mathrm{Na}^{+}$and $\mathrm{Cl}^{-}$concentrations in sorghum genotypes were very low, while there were no substantial differences in $\mathrm{Ca}^{2+}$ and $\mathrm{Mg}^{2+}$ between the two crops. Sorghum had high ability of $\mathrm{Na}^{+}$exclusion from shoots, while maize genotypes had extremely high uptake of $\mathrm{Na}^{+}$in shoots.

Plant adaptations to salinity are of three distinct types: osmotic stress tolerance, $\mathrm{Na}^{+}$and/or $\mathrm{Cl}^{-}$exclusion, and the tissue tolerance of high concentrations of $\mathrm{Na}^{+}$and/or $\mathrm{Cl}^{-}$ [4]. Some species tolerate salt stress by avoiding uptake of certain ions or by tolerating high ion concentrations in the tissue. In maize, all genotypes had high $\mathrm{Na}^{+}$concentrations in stems and leaves, ranged from $7.35 \mathrm{mg} \mathrm{g}^{-1}$ to $22.18 \mathrm{mg} \mathrm{g}^{-1}$ in the leaves and from $31.93 \mathrm{mg} \mathrm{g}^{-1}$ to $41.58 \mathrm{mg} \mathrm{g}^{-1}$ in stems. These concentrations are in the high range for most glycophyte. Similar high $\mathrm{Na}^{+}$concentrations in maize genotypes were reported $[5,18,21,29]$. However, at similar $\mathrm{NaCl}$ salinity $(100 \mathrm{mM})$, Turan et al. [25] reported a lower shoot $\mathrm{Na}^{+}$concentration of $4.46 \mathrm{mg} \mathrm{g}^{-1}$ for a maize cv: $\mathrm{RX}$ 947, while its shoot $\mathrm{Cl}^{-}$concentration was $44.16 \mathrm{mg} \mathrm{g}^{-1}$, which was not substantially different from those in this study. These differences could be due to genotype, experimental duration, growth stage, and fertility. 
Sorghum genotypes had extremely low $\mathrm{Na}^{+}$concentrations with little extra uptake of $\mathrm{Na}^{+}$in the salt-treated plants compared to those in the control. Low $\mathrm{Na}^{+}$concentrations in sorghum leaves and stems at similar salinity were reported by other researchers [18]. Other cereal crops such as wheat had lower tissue $\mathrm{Na}^{+}$concentrations than those of maize cultivars [29]. Apparently, maize genotypes coped with salt stress by tolerating high $\mathrm{Na}^{+}$and $\mathrm{Cl}^{-}$concentrations, while sorghum genotypes had high ability of excluding $\mathrm{Na}^{+}$from shoots.

\section{Conclusion}

Responses of maize and sorghum to salinity differed among genotypes. Based on growth and visual salt damage, in maize, CUBA1 was relatively tolerant to salinity, followed by B73 and $\mathrm{B} 5 \mathrm{C} 2$; $\mathrm{BR} 1$ was the least tolerant, although the differences among the four genotypes were small. In sorghum, Sordan79 was the most tolerant, followed by SS304; KS585 was the least tolerant among the four sorghum genotypes and was less tolerant than BR1 in terms of its visual salt damage and great shoot growth reduction. Maize genotypes accumulated $\mathrm{Na}^{+}$excessively in shoots, while sorghum had high ability to exclude $\mathrm{Na}^{+}$uptake from shoots. Both visual foliar salt damage of the seedlings and growth parameters are reliable criteria for assessing salt tolerance among genotypes for both crops, while physiological responses to salinity are useful information for breeding programs and help understand the mechanisms of salt tolerance of the crops.

\section{References}

[1] F.A.O., Global Network on Integrated Soil Management for Sustainable Use of Salt-Affected Soils, FAO Land and Plant Nutrient Management Service, 2005.

[2] A. D. Azevedo Neto, J. T. Prisco, J. Enéas-Filho, C. E. B. D. Abreu, and E. Gomes-Filho, "Effect of salt stress on antioxidative enzymes and lipid peroxidation in leaves and roots of salt-tolerant and salt-sensitive maize genotypes," Environmental and Experimental Botany, vol. 56, no. 1, pp. 8794, 2006.

[3] X. Cai, X. Zhang, and D. Wang, "Land availability for biofuel production," Environmental Science and Technology, vol. 45, no. 1, pp. 334-339, 2011.

[4] R. Munns and M. Tester, "Mechanisms of salinity tolerance," Annual Review of Plant Biology, vol. 59, pp. 651-681, 2008.

[5] E. B. Carpici, N. Celik, G. Bayram, and B. B. Asik, "The effects of salt stress on the growth, biochemical parameter and mineral element content of some maize (Zea mays L.) cultivars," African Journal of Biotechnology, vol. 9, no. 41, pp. 6937-6942, 2010.

[6] E. V. Maas and G. J. Hoffman, "Crop salt tolerance-current assessment," Journal of the Irrigation and Drainage Division, vol. 103, no. 2, pp. 115-134, 1977.

[7] S. A. E. Ouda, S. G. Mohamed, and F. A. Khalıl, "Modeling the effect of different stress conditions on maize productivity using yield-stress model," International Journal of Natural and Engineering Sciences, vol. 2, no. 1, pp. 57-62, 2008.

[8] E. Igartua, M. P. Gracia, and J. M. Lasa, "Field responses of grain sorghum to a salinity gradient," Field Crops Research, vol. 42, no. 1, pp. 15-25, 1995.
[9] E. V. Maas, "Crop tolerance to saline sprinkling water," Plant and Soil, vol. 89, no. 1-3, pp. 273-284, 1985.

[10] F. M. Azhar and T. McNeilly, "Variability for salt tolerance in Sorghum bicolor (L) Moench under hydroponic conditions," Journal of Agronomy and Crop Science, vol. 159, no. 4, pp. 269277, 1987.

[11] F. M. Azhar and T. McNeilly, "The genetic basis of variation for salt tolerance in Sorghum bicolor (L) Moench seedlings," Plant Breeding, vol. 101, no. 2, pp. 114-121, 1988.

[12] L. Krishnamurthy, R. Serraj, C. T. Hash, A. J. Dakheel, and B. V. S. Reddy, "Screening sorghum genotypes for salinity tolerant biomass production," Euphytica, vol. 156, no. 1-2, pp. 15-24, 2007.

[13] S. Partners, Product Profiles-KS585, NK7829, SS304, and Sordan79, Sorghum Partners, INC, New Deal, Tex, USA, 2009.

[14] Q. Wang, J. Chen, R. H. Stamps, and Y. Li, "Correlation of visual quality grading and SPAD reading of green-leaved foliage plants," Journal of Plant Nutrition, vol. 28, no. 7, pp. 1215-1225, 2005.

[15] U.S. Environmental Protection Agency, Methods of Chemical Analysis of Water and Wastes (EPA-600/4-79-020), Cincinnati, Ohio, USA, 1983.

[16] R. Munns, "Physiological processes limiting plant growth in saline soils: some dogmas and hypotheses," Plant, Cell \& Environment, vol. 16, no. 1, pp. 15-24, 1993.

[17] R. Munns, "Comparative physiology of salt and water stress," Plant, Cell and Environment, vol. 25, no. 2, pp. 239-250, 2002.

[18] G. W. Netondo, J. C. Onyango, and E. Beck, "Sorghum and salinity: I. Response of growth, water relations, and ion accumulation to $\mathrm{NaCl}$ salinity," Crop Science, vol. 44, no. 3, pp. 797-805, 2004.

[19] G. Niu and D. S. Rodriguez, "Responses of growth and ion uptake of four rose rootstocks to chloride- or sulfatedominated salinity," Journal of the American Society for Horticultural Science, vol. 133, no. 5, pp. 663-669, 2008.

[20] C. N. Deng, G. X. Zhang, X. L. Pan, and K. Y. Zhao, "Chlorophyll fluorescence and gas exchange responses of maize seedlings to saline-alkaline stress," Bulgarian Journal of Agricultural Science, vol. 16, no. 1, pp. 49-58, 2010.

[21] M. Akram, M. Y. Ashraf, M. Jamil, R. M. Iqbal, M. Nafees, and M. A. Khan, "Nitrogen application improves gas exchange characteristics and chlorophyll fluorescence in maize hybrids under salinity conditions," Russian Journal of Plant Physiology, vol. 58, no. 3, pp. 394-401, 2011.

[22] G. W. Netondo, J. C. Onyango, and E. Beck, "Sorghum and salinity: II. Gas exchange and chlorophyll fluorescence of sorghum under salt stress," Crop Science, vol. 44, no. 3, pp. 806-811, 2004.

[23] Y. Demir and I. Kocacaliskan, "Effects of proline on maize embryos cultured in salt stress," Fresenius Environmental Bulletin, vol. 17, no. 5, pp. 536-542, 2008.

[24] A. M. A. Magnaye, P. J. A. Santos, and P. C. S. Cruz, "Responses of yellow maize (Zea mays L.) inbreds to salinity," Asia Life Sciences, vol. 20, no. 2, pp. 521-533, 2011.

[25] M. A. Turan, A. H. A. Elkarim, N. Taban, and S. Taban, "Effect of salt stress on growth, stomatal resistance, proline and chlorophyll concentrations on maize plant," African Journal of Agricultural Research, vol. 4, no. 9, pp. 893-897, 2009.

[26] R. Chaabane, H. Bchini, H. Ouji et al., "Behaviour of Tunisian durum wheat (Triticum turgidum L.) varieties under saline stress," Pakistan Journal of Nutrition, vol. 10, no. 6, pp. 539542, 2011. 
[27] M. Jamil, S. U. Rehman, J. L. Kui, M. K. Jeong, H. S. Kim, and S. R. Eui, "Salinity reduced growth PS2 photochemistry and chlorophyll content in radish," Scientia Agricola, vol. 64, no. 2, pp. 111-118, 2007.

[28] M. Heidari, "Effects of salinity stress on growth, chlorophyll content and osmotic components of two basil (Ocimum basilicum L.) genotypes," African Journal of Biotechnology, vol. 11, no. 2, pp. 379-384, 2012.

[29] M. Goudarzi and H. Pakniyat, "Comparison between salt tolerance of various cultivars of wheat and maize," Journal of Applied Sciences, vol. 8, no. 12, pp. 2300-2305, 2008. 


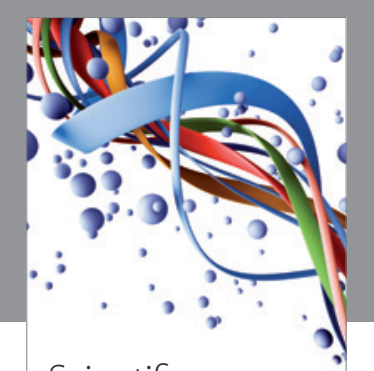

Scientifica
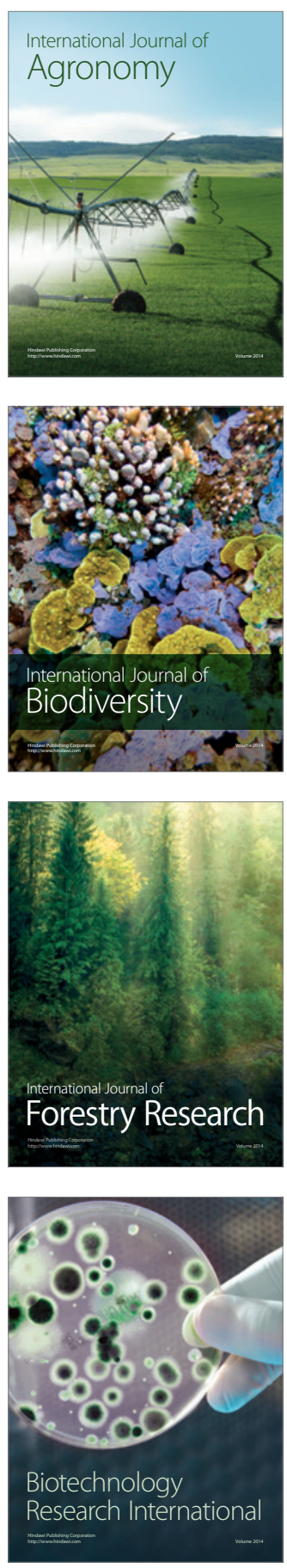
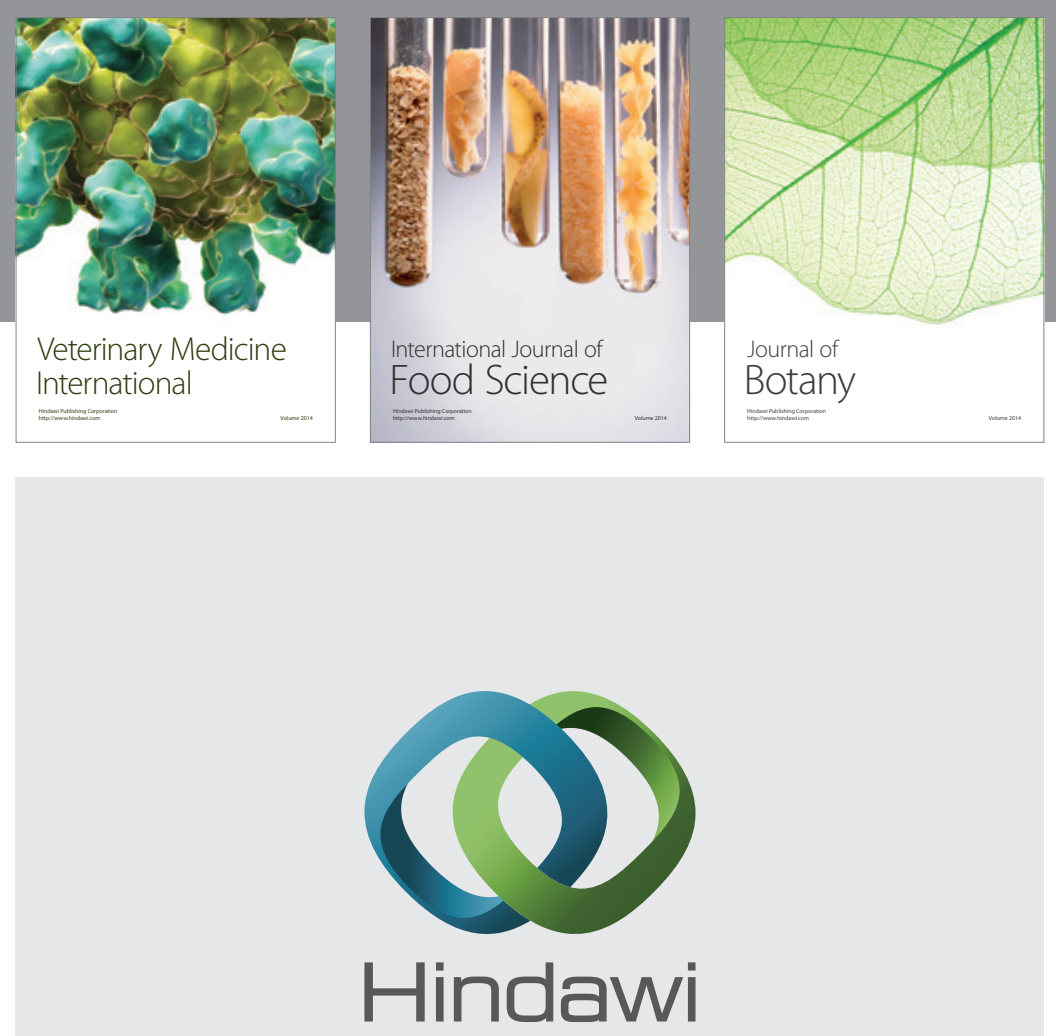

Submit your manuscripts at

http://www.hindawi.com
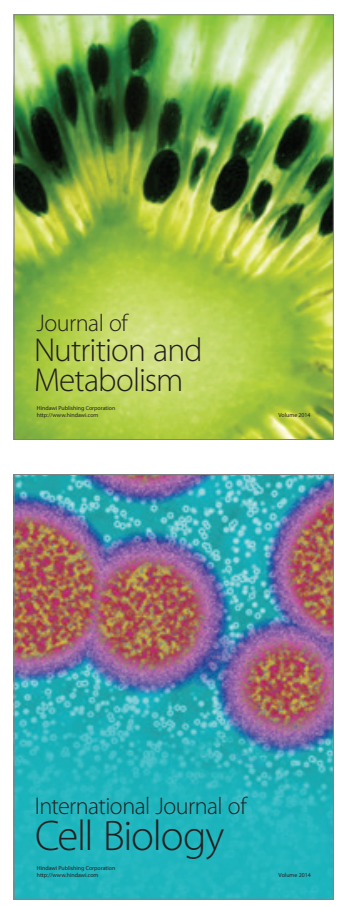
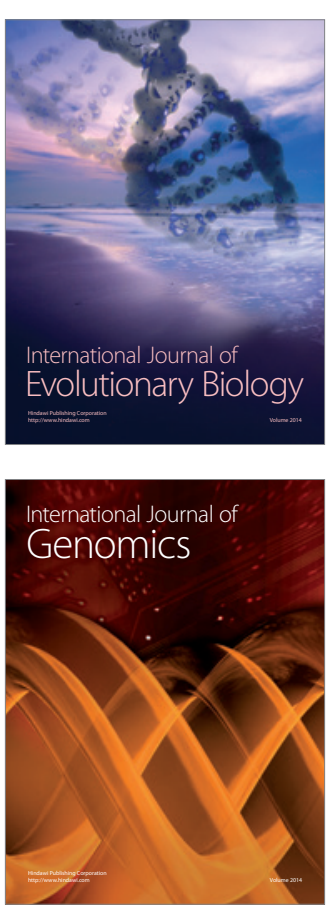
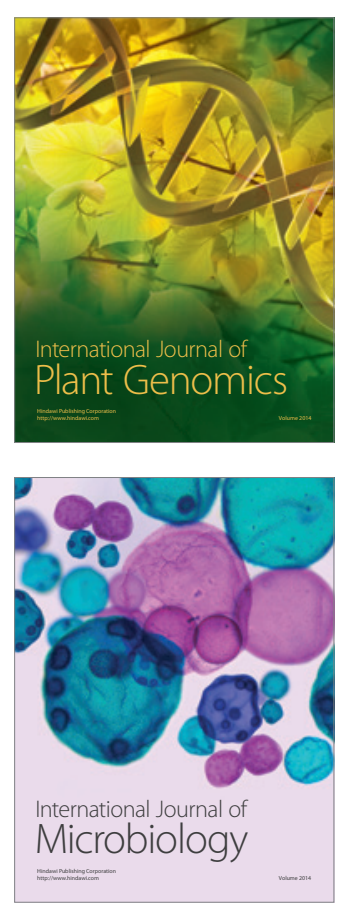

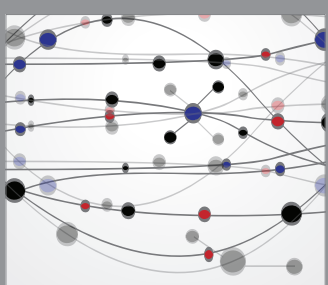

The Scientific World Journal
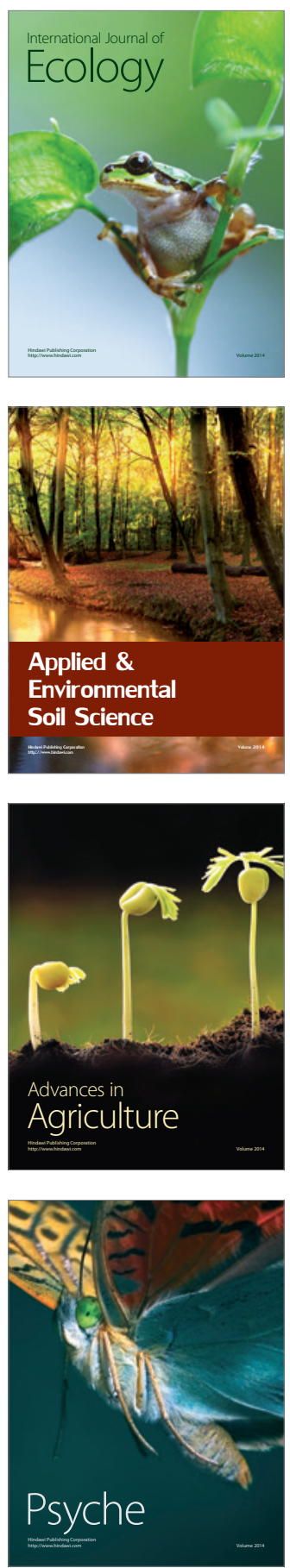